\title{
Proceeding
}

Supplementary Issue: Spring Conferences of Sports Science. 15th Convention and Workshop of the International Network of Sport and Health Science, 5-8 June 2019. University of Las Palmas de Gran Canaria, Las Palmas de Gran Canaria, Spain.

\section{Effects induced through the use of physical and motor tests in volleyball}

\author{
CIRO ALMINNI ${ }^{1} \triangle$, GAETANO ALTAVILLA ${ }^{2}$, RAFFAELE SCURATI ${ }^{3}$, FRANCESCA D'ELIA ${ }^{1}$ \\ 1 University of Salerno, Italy \\ 2 University of Split, Croatia \\ ${ }^{3}$ Department of Biomedical Sciences for Health, University of Milan, Italy
}

\begin{abstract}
The purpose of the study was to analyse and evaluate the jumping ability and the fundamental technical of the float serve in volleyball in 3 areas of the opposing camp (1-6-5), in order to evaluate the effectiveness of a working method. The study was performed on a sample of 12 male volleyball players (Category: Under 20). Data were collected in two periods (September and October), subjecting the players to intensive technical and physical work. At the beginning of the training period anthropometrics data (weight, height, BMl, reach to one hand) and the values at the vertec jump test were collected. Each player carried out 90 float services ( 3 series of 30 float serves, respectively to specific areas of the opponent's field 1-6-5) to check out if there is continuity of precision towards the three zones or if there is a significant difference. The results show, after four weeks of intensive training, an improvement in jumping ability at the Vertec test. It is hypothesized a not significant difference in the performance by the group of players, in terms of precision, towards the three opposing areas and a positive difference in pre-training (September) and post-training (October) performances. The monitoring of the training process will allow to estimate the effects induced through the use of physical and motor tests, allowing the coaches to design and choose the methodology and the appropriate training load, for an effective performance. Keywords: Float serve; Test and monitoring; Intensive training; Performance.
\end{abstract}

\section{Cite this article as:}

Alminni, C., Altavilla, G., Scurati, R., \& D'Elia, F. (2019). Effects induced through the use of physical and motor tests in volleyball. Journal of Human Sport and Exercise, 14(4proc), S618-S623. doi:https://doi.org/10.14198/ihse.2019.14.Proc4.20

Corresponding author. University of Salerno, Italy.

E-mail: alminni2013@gmail.com

Supplementary Issue: Spring Conferences of Sports Science. 15th Convention and Workshop of the International Network of Sport and Health Science, 5-8 June 2019. University of Las Palmas de Gran Canaria, Las Palmas de Gran Canaria, Spain. JOURNAL OF HUMAN SPORT \& EXERCISE ISSN 1988-5202

(c) Faculty of Education. University of Alicante doi:10.14198/jhse.2019.14.Proc4.20 


\section{INTRODUCTION}

Volleyball is a sport with technical and physical characteristics (D'Elia et al, 2019) where the precision and the power are the most important aspect for achieve a winning action (Ferrara et al, 2018, D'santo et al, 2017). In modern volleyball the use of the jump and the speed of play is a clear sign of a greater demand for physical strength (Forte et al, 2019)and the speed of the technical gesture (Raiola, \& Di Tore, 2017). The performance is also linked to other qualities such as neuro-muscular coordination (Raiola, 2014), motor control (Raiola, 2017), tactical attitudes and motivational characteristics (D'Isanto et al, 2018). The volleyball is a sport considered of attack because it is what determines the points, also if you are wrong you gives the point to the opponent, or you will give the chance to the opponent to attack and achieve point; all actions always end with a point for a team (Raiola et al, 2016). In this sport the serve represents the first attack with effect immediate on the successive defensive and offensive actions of the opposing team. To test the players is indispensable for several reasons: allows us to evaluate their potentials (Alminni et al., 2019), their athletic and technical qualities (D'santo et al, 2019); for example, for a particular skill needed during a match of volleyball such as a precision's serve. To set up a correct training methodology (D'Isanto et al, 2017) and, finally, to verify and monitor the effectiveness of training and changes in physical condition (Forte \& Altavilla, 2018). The study wants to analyse and evaluate the ability to jump (Altavilla et al, 2018abc), explosive actions are elements of success (Altavilla \& Raiola, 2019) and technical skills in the fundamental of the float serve in volleyball (Parisi, Raiola, 2014), verifying the effects induced, both in performance and precision, after a 4week training period. The aim of the study has been to analyse and evaluate the jumping ability and the fundamental technical of the float serve in volleyball in 3 areas of the opposing camp (1-6-5), in order to evaluate the effectiveness of a working method.

\section{METHODS}

The sample of the subjects is represented by young male volleyball players $(n=12)$ eighteen and nine teen years old. All players participate at Italian championship (Category: Under 20). They have voluntarily participated in this research.

The tests carried out before and after the 4-week training period are:

Anthropometrics test

- Height (cm).

- Weight $\mathrm{kg})$.

- $\operatorname{BMI}\left(\mathrm{Kg} / \mathrm{m}^{2}\right)$.

- One-handed Reach (cm).

\section{Test physical skills}

- Vertec jump test: the athlete makes a run-up and tries to touch as high as possible with the dominant hand; each athlete makes three jumps, performed after a fair recovery. At the end of the three jumps, we calculate the average value which is taken as the reference value for the test performed. Moreover, by subtracting from the average three jumps the value of the one-handed reach is obtained the value of the differential from the ground of the jump.

- Technical skills test.

- Float serve: each player must perform 3 series of 30 float serves, respectively to specific areas of the opponent's field (zone 1, 6 and 5). 


\section{Statistical analysis}

Measures of central tendency and dispersion (mean \pm standard deviation) of height, weight, BMI and Onehanded Reach of a group (12 subjects). Height: $182 \pm 5.51$; Weight: 73,6 \pm 7.23 ; BMl: 22,32 \pm 1.33 ; Onehanded Reach: $232,2 \pm 7,08$ ). A t-test for dependent groups was conducted to check the differences between the pre-post (Vertec Jump and Float Serve) and relative percentages to improvement. Analysis of Variance (ANOVA) has been used to show the no significant differences in the performance by the group of players, towards the three opposing areas, in term of precision in the float serve. The significance level was set at $p<0.05$. Statistical analyses will be carried out with the software «IBM SPSS23».

\section{RESULTS}

Table 1. Anthropometrics data

\begin{tabular}{ccc}
\hline Group $(\mathbf{n = 1 2})$ & Average & Standard Deviation \\
\hline Age (year) & 19.1 & 0.86 \\
Height $(\mathbf{c m})$ & 181.5 & 5,51 \\
Weight $(\mathbf{k g})$ & 73.6 & 7,23 \\
BMI $\left(\mathbf{k g} / \mathbf{~ m}^{2}\right)$ & 22,3 & 1,33 \\
One-handed rech $(\mathbf{m})$ & 232,2 & 7,08 \\
\hline
\end{tabular}

Table 2. Difference jump between pre (September) and post (October)

\begin{tabular}{cccccc}
\hline \multicolumn{5}{c}{ 04-September } & \multicolumn{2}{c}{ 02-October } & \\
\hline Player & Average & $\begin{array}{c}\text { Difference } \\
\text { Jump }\end{array}$ & Average & $\begin{array}{c}\text { Difference } \\
\text { Jump }\end{array}$ & $\begin{array}{c}\text { Diff. Jump } \\
\text { Test 1- Test 2 }\end{array}$ \\
\hline 1 & 291,3 & 64,3 & 295,3 & 68,3 & 4,0 \\
2 & 282,0 & 57,0 & 282,7 & 57,7 & 0,7 \\
3 & 299,0 & 61,0 & 304,7 & 66,7 & 5,7 \\
4 & 297,3 & 53,3 & 304,7 & 60,7 & 7,3 \\
5 & 295,7 & 60,7 & 299,3 & 64,3 & 3,7 \\
6 & 291,3 & 60,3 & 292,0 & 61,0 & 0,7 \\
7 & 291,3 & 54,3 & 294,7 & 57,7 & 3,3 \\
8 & 292,7 & 69,7 & 298,7 & 75,7 & 6,0 \\
9 & 285,3 & 54,3 & 286,0 & 55,0 & 0,7 \\
10 & 293,3 & 52,3 & 294,0 & 53,0 & 0,7 \\
11 & 281,3 & 59,3 & 286,7 & 64,7 & 5,3 \\
12 & 291,2 & 58,7 & 294,5 & 62,1 & 3,5 \\
\hline Mean & $\mathbf{2 9 1 , 0}$ & $\mathbf{5 8 , 8}$ & $\mathbf{2 9 4 , 4}$ & $\mathbf{6 2 , 2}$ & $\mathbf{3 , 4 5}$ \\
\hline Standard & $\mathbf{5 , 5 7}$ & $\mathbf{5 , 0 0}$ & $\mathbf{6 , 9 3}$ & $\mathbf{6 , 2 6}$ & $\mathbf{2 , 3 6}$ \\
Deviation & & & &
\end{tabular}


Table 3. T-test - Significant difference with $p=0,001$ between the two series of jump

\begin{tabular}{|c|c|c|c|c|c|c|c|c|}
\hline & \multicolumn{5}{|c|}{ Paired differences } & \multirow{3}{*}{$\mathrm{t}$} & \multirow{3}{*}{ gl } & \multirow{3}{*}{ Sign. } \\
\hline & \multirow[t]{2}{*}{ Media } & \multirow[t]{2}{*}{ SD } & \multirow{2}{*}{$\begin{array}{c}\text { Average } \\
\text { Standard } \\
\text { Error }\end{array}$} & \multicolumn{2}{|c|}{$\begin{array}{c}95 \% \text { confidence } \\
\text { interval difference }\end{array}$} & & & \\
\hline & & & & Lower & Higher & & & \\
\hline $\begin{array}{ll}\text { Couple } 1 & \text { VAR00001 } \\
\text { VAR00002 }\end{array}$ & -3.48182 & 2.48065 & .74794 & -5.14834 & -1.81529 & 4.655 & 10 & .001 \\
\hline
\end{tabular}

Table 3 shows a significant difference between the two series of jumps performed before (September) and after (October) the period of 4 weeks of intense training $(p=0.001)$, so there was a significant increase in jumping performances.

Table 4. Float serve in the three areas (1,6 and 5$)$

\begin{tabular}{|c|c|c|c|c|}
\hline & \multicolumn{2}{|c|}{ 04-Sept } & \multicolumn{2}{|c|}{ 02-0ct } \\
\hline & $X$ & 0 & $X$ & 0 \\
\hline Total & 208 & 152 & 162 & 198 \\
\hline Positiveness & \multicolumn{2}{|c|}{$42.2 \%$} & \multicolumn{2}{|c|}{$55.0 \%$} \\
\hline
\end{tabular}

\section{Estimating of training effect: $12.8 \%$}

Table 4 shows the results of the float service performed by the group of players in the period preceding the training (in September it was 42.2\%) and after the training period (in October it was 55.0\%). Performances improved by $12.8 \%$.

Table 5. Training hours report between pre and post

\begin{tabular}{ll}
\hline Physical training & $6 \mathrm{~h} 00^{\prime}$ \\
Technique & $10 \mathrm{~h}^{\prime}$ \\
Phases of game & $10 \mathrm{~h}^{\prime}$ \\
\hline Total & $26 \mathrm{~h} 00^{\prime}$ \\
\hline
\end{tabular}

Table 5 shows the workload (physical, technical and tactical) dispensed during the four weeks of intensive training, specifying the distribution of work in hours.

Table 6. T-test, significant difference between two positiveness series (pre and post) on float serve

\begin{tabular}{|c|c|c|c|c|c|c|c|c|c|}
\hline & \multicolumn{5}{|c|}{ Paired differences } & \multirow{3}{*}{$t$} & \multirow{3}{*}{ gl } & \multirow{3}{*}{ Sign. } \\
\hline & & \multirow[t]{2}{*}{ Main } & \multirow[t]{2}{*}{ SD } & \multirow{2}{*}{$\begin{array}{c}\text { Average } \\
\text { Standard } \\
\text { error }\end{array}$} & \multicolumn{2}{|c|}{$\begin{array}{c}95 \% \text { confidence } \\
\text { interval difference }\end{array}$} & & & \\
\hline & & & & & Lower & Higher & & & \\
\hline $\begin{array}{l}\text { Couple } \\
1\end{array}$ & $\begin{array}{l}\text { VAR00001 } \\
- \\
\text { VAR00002 }\end{array}$ & 1.91667 & .28868 & 08333 & 2.10008 & -1.73325 & -23.000 & 11 & .000 \\
\hline
\end{tabular}

Table 6 shows a significant difference between the two series of float service hit (positive) performed before (September) and after (October) the period of 4 weeks of intense training $(p=0.000)$. 
Table 7. Anova, no significant difference between the series of float serves in zone 1, 6, and 5

\begin{tabular}{cccc}
\hline Float serves & Series of float serves centred in October & $\mathbf{F}$ & $\mathbf{P}$ \\
\hline Zone opponent 1 & $64 / 120$ & 1,125 & 0,566 \\
Zone opponent 6 & $68 / 120$ & 1,667 & 0,226 \\
Zone opponent 5 & $66 / 120$ & 0,500 & 0,622 \\
Total serves centred & $198 / 360$ & &
\end{tabular}

Anova's test shows that there was no significant difference, about precision, in the three series of float service carried out in three different areas of the opposing field $(1,6,5)$; therefore for the purpose of performance, in the series of floating services in the three opposing field zones $(1,6,5)$, there was, in terms of precision, a very similar performance.

\section{DISCUSSION AND CONCLUSIONS}

Through statistical processing (t-test with $p<0.05$ ) of the data, it emerged that following the training sessions carried out in the four weeks between pre-post intensive training, an average increase of $3.45 \mathrm{~cm}$ was recorded in the differential jump to the vertec jump test. In data processing, statistics and parametrics (t-test with $p<0.05$ ) on the float jump service to the 3 zones of the opposing field, the services that hit the target zone increased from 152 to $360(42.2 \%)$ to 198 out of $360(55 \%)$ with an increase in the accuracy of this specific service of $12.8 \%$. Using the statistical test of Anova he showed that there was no significant difference in terms of precision in the three series of float service towards the three zones of the opposing field (64 in zone 1, 68 in zone 6,66 in zone 5) and thus, we can affirm a performance in terms of precision very similar. This work is a pilot study for the small sample size (12 players) and for the shortness of the route between the incoming and outgoing tests ( 4 weeks). The test is a tool that allows you to have a very effective periodic check and thanks to the analysis of its results and the feedback received, it is possible to correlate the performance with the work strategies adopted. Therefore, with this operational strategy, it is possible to identify which are the best adaptations to be made to the training program that is given to the athletes. In order to optimize monitoring and programming, this study is repeated several times during the competitive season (preparation phase - sampled phase - at the end of the championship) to periodically check if there are improvements in physical and technical performance.

\section{REFERENCES}

Alminni, C., Altavilla, G., Cassese, F.P., Ceciliani, A., D'isanto, T. (2019) Physical and motor tests to estimate the improvement of the float serve, Journal of Human Sport and Exercise, 14 (Proc2), pp. S245-S250. https://doi.org/10.14198//hse.2019.14.proc2.13

Altavilla, G., \& Raiola, G. (2019). A brief review on physiological commitment in basketball: An interpretative key, Journal of Human Sport and Exercise, 14(1): 59-65. https://doi.org/10.14198/ihse.2019.14.proc1.07

Altavilla, G., D'isanto, T., Di Tore, P.A. (2018a). Anthropometrics characteristics and jumping ability in basketball, Journal of Human Sport and Exercise, 13(2): 385-392. https://doi.org/10.14198/ihse.2018.13.proc2.22 
Altavilla, G., D'Isanto, T., Di Tore, A.P., Raiola, G. (2018b) Free throw and outcomes: Pilot study on intensive training versus extensive one, Journal of Human Sport and Exercise, 13 (3), pp. 494-503. https://doi.org/10.14198/hihse.2018.133.02

Altavilla, G., Mazzeo, F., D'Elia, F., Raiola, G. (2018c) Physical commitment and specific work for each role in an elite soccer team, Journal of Physical Education and Sport, 18 (2), art. no. 83, pp. 570 574.

D'Elia, F., D'Isanto, T., \& Altavilla, G. (2019). Training and performance in the transition period. Journal of Human Sport and Exercise, 14(2proc), S258-S262. https://doi.org/10.14198/ihse.2019.14.Proc2.15

D'santo, T., D'Elia, F., Raiola, G., Altavilla, G. (2019). Assessment of sport performance: theoretical aspects and practical indications. Sport Mont, 17(1): 79-82. https://doi.org/10.26773/smj.190214

D'Isanto, T., Di Tore, P.A., Altavilla, G. (2018). Correlation of the anthropometric characteristics and the ability to jump in volleyball, Journal of Human Sport and Exercise, 13(2): 393-400. https://doi.org/10.14198/ihse.2018.13.proc2.23

D'Isanto, T., Altavilla, G., Raiola, G. (2017). Teaching method in volleyball service: Intensive and extensive tools in cognitive and ecological approach. Journal of Physical Education and Sport, 17(S5): 2222-2227.

Ferrara, F., Di Tore, P.A., Gaetano, R. (2018) Preliminary work on the testing of power glove applied to volleyball, Journal of Physical Education and Sport, 18, art. no. 294, pp. 1986-1990.

Forte, D., Ceciliani, A., Izzo, R., Altavilla, G. (2019) Transition period: Pilot study on performance reduction of ability to jump in volleyball, Journal of Human Sport and Exercise, 14 (Proc2), pp. S221S227. https://doi.org/10.14198//hse.2019.14.proc2.09

Forte, D., Altavilla, G. (2018). Preliminary correlation between anthropometric and performance data in volleyball about the transition period, Journal of Physical Education and Sport, 18(S5): 1994-1998.

Gaetano, R. (2012) Didactics of volleyball into the educate program for coaches/trainers/technicians of Italian Federation of Volleyball (FIPAV) Journal of Physical Education and Sport, 12 (1), pp. 25-29.

Parisi, F., Raiola, G. (2014) The serve in under 12-13 Italian volleyball team, Journal of Human Sport and Exercise, 9, pp. S588-S591. https://doi.org/10.14198/jhse.2014.9.proc1.51

Raiola, G. (2017). Motor learning and teaching method, Journal of Physical Education and Sport, 17(S5): 2239-2243.

Raiola, G., Di Tore, P.A. (2017). Motor learning in sports science: Different theoretical frameworks for different teaching methods, Sport Science, 10(S1): 50-56.

Raiola, G., Altavilla, G., De Luca, C., Di Tore, P.A. (2016). Analysis on some aspects of the service in volleyball, Sport Science, 9 (1): 74-77.

Raiola, G. (2014). Teaching method in young female team of volleyball, Journal of Physical Education and Sport, 14 (1): 74-78.

Raiola, G., Di Tore, P.A. (2012) Statistical study on bodily communication skills in volleyball to improve teaching methods, Journal of Human Sport and Exercise, 7 (2), pp. 468-488. https://doi.org/10.4100/jhse.2012.72.12

Raiola, G., Di Tore, P.A. (2012) Bodily communication skills and its incidence on female volleyball championship to enhance didactics, Journal of Human Sport and Exercise, 7 (2), pp. 365-375. https://doi.org/10.4100/jhse.2012.72.03

\section{(9) $(\mathbb{Q} \Theta \Theta$}

This work is licensed under a Attribution-NonCommercial-NoDerivatives 4.0 International (CC BY-NC-ND 4.0). 